\title{
Effects of the longitudinal and transversal structural grain morphologies upon the corrosion resistance of zinc and aluminium specimens
}

\author{
W.R. Osório*, C.A. Siqueira*, C. M-A. Freire*and A. García*
}

\begin{abstract}
Several different structural morphologies may develop due to a wide range of the operational conditions that may exist during solidification. It was reported that the structural morphology affects the corrosion resistance. The aim of this study is to investigate the influence of the longitudinal (columnar) and transversal (equiaxed) structures of the same sample upon the corrosion resistance of pure aluminium and zinc castings. In order to obtain both longitudinal and transversal structures a vertical upward solidification apparatus was used. The corrosion resistance was analysed by the EIS and Tafel extrapolation methods in a $3 \% \mathrm{NaCl}$ solution. The investigation has shown that both structures present similar corrosion behavior.
\end{abstract}

Keywords Structural morphologies. Solidification. Grain size. Corrosion. Zinc and aluminium.

\section{Efecto de las morfologías estructurales longitudinales y transversales en la resistencia a corrosión de las muestras del cinc y aluminio}

\begin{abstract}
Resumen Diferentes morfologías estructurales pueden desarrollarse debido a la amplia gama de condiciones operacionales que pueden existir durante la solidificación. Se ha publicado que la morfología estructural afecta a la resistencia a la corrosión. El objetivo de este trabajo es investigar la influencia de las estructuras longitudinales (columnares) y transversales (equiaxiales) en la resistencia a la corrosión de muestras de aluminio y cinc puros. Para obtener las estructuras se usó un aparato con solidificación vertical ascendente. La resistencia a corrosión se analizó por métodos de EIS y polarización Tafel en solución $3 \%$ $\mathrm{NaCl}$. Se concluyó que ambas estructuras presentan similares comportamientos frente a la corrosión.
\end{abstract}

Palabras clave Morfología estructural. Solidificación. Tamaño de granos. Corrosión. Cinc y aluminio.

\section{INTRODUCTION}

It is well known that mechanical properties depend on solidification structure. The literature presents several papers relating mechanical and microstructural properties ${ }^{[1]}$ like yield strength and grain size $\mathrm{e}^{[2-4]}$ or ultimate tensile strength and secondary dendrite spacing ${ }^{[5}$ and 6$]$. Several different structural morphologies may develop due to a wide range of operational conditions and various growth forms during the solidification process. It is also well known that structural parameters are strongly influenced by thermal behavior of the metal/mold system imposing a close correlation with the resulting solidification structures ${ }^{[5-9]}$ and affecting the mechanical behavior. On the other hand, the structural morphologies also play an important role in the corrosion behavior of materials. A number of experimental studies have pointed up effects of the structure upon the corrosion resistance by various structural forms, in a number of processes $^{[10-16]}$. Therefore, it is clear that structural parameters including alloy composition, porosity ${ }^{[17]}$, grain size ${ }^{[2}$ and 18$]$ and both amount and homogeneity distribution of second phases ${ }^{[5}$ and 7$]$ can also be important parameters for both mechanical and corrosion properties. The aim of this paper is to investigate the influence of two different solidification structures on the same sample of zinc and aluminium specimens. Both

$\left({ }^{*}\right)$ Department of Materials Engineering, State University of Campinas, UNICAMP, P.O. Box 6122, 13083 - 970, Campinas, SP, Brazil. 
columnar and equiaxed structures were analysed by using longitudinal and transversal sections of the same sample.

\section{MATERIALS AND EXPERIMENTAL PROCEDURE}

During solidification, heat flow conditions and the preferential growth crystallography are parameters that control the growth direction of columnar grains, which consist of a band of elongated crystals parallel to the direction of heat flow. The equiaxed structure is characterized by the growth of grains of different orientations and neighbouring grains are not necessarily parallel to each other, as is the case for columnar grains ${ }^{[19]}$. In this study, the equiaxed structures were obtained from transversal sections of the ingot presenting columnar structure as shown in figure 1 . The columnar structures of both aluminium and zinc samples were obtained by using a water-cooled vertical upward solidification system which is detailed in a previous article ${ }^{[20]}$. The chemical composition of $\mathrm{Al}$ and $\mathrm{Zn}$ samples are shown in table I. In order to compare the corrosion resistance exhibited by both structures, corrosion tests were performed in longitudinal and transversal sections, which are columnar and equiaxed respectively. A concentrated hydrochloride acid and $\mathrm{HCl}, \mathrm{HNO}_{3}$ and $\mathrm{HF}$ acid solutions $^{[21]}$ were used, respectively, to reveal $\mathrm{Zn}$ and $\mathrm{Al}$ macrostructures.

Although accelerated corrosion testing is widely used since the early 1900 s $^{[22]}$, for some particular situations, the excessive aggressiveness of the used solution could mask the real materials performance in the initial stage of the corrosive phenomenon ${ }^{[23]}$.

The electrochemical techniques and the polarization method were chosen to investigate the material corrosion performance.

In the present paper, the experimental electrochemical impedance spectroscopy (EIS) tests were conducted in a $3 \% \mathrm{NaCl}$ solution at room temperature by using an EG \& G Princeton Applied Research, model 273A potentiostat coupled to a frequency analyser system, SOLARTRON model 1250, a glass corrosion cell kit with the working electrodes ( $\mathrm{Zn}$ and $\mathrm{Al}$ samples), a plate platinum counter-electrode and saturated calomel reference electrode (SCE) as prescribed by the ASTM standard G3 ${ }^{[24]}$.

The polarization tests (PT) were also conducted in a $3 \% \mathrm{NaCl}$ solution at room temperature by using the above mentioned potentiostat in a scan rate of $0.2 \mathrm{mV} / \mathrm{s}$ from $-250 \mathrm{mV}$ (SCE) to $+250 \mathrm{mV}$ (SCE) in an open-circuit and an automatic data acquisition system. The polarization curves were plotted and both corrosion current and corrosion potential were calculated by the Tafel

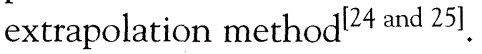

The EIS tests were performed between a 100 $\mathrm{mHz}$ and $100 \mathrm{kHz}$ frequency range. Before each corrosion test, the as-cast specimens were ground by using a $600 \mathrm{SiC}$ grinding paper, cleaned and dried by airflow. The EIS and polarization tests were performed during 15 and $40 \mathrm{~min}$, respectively.

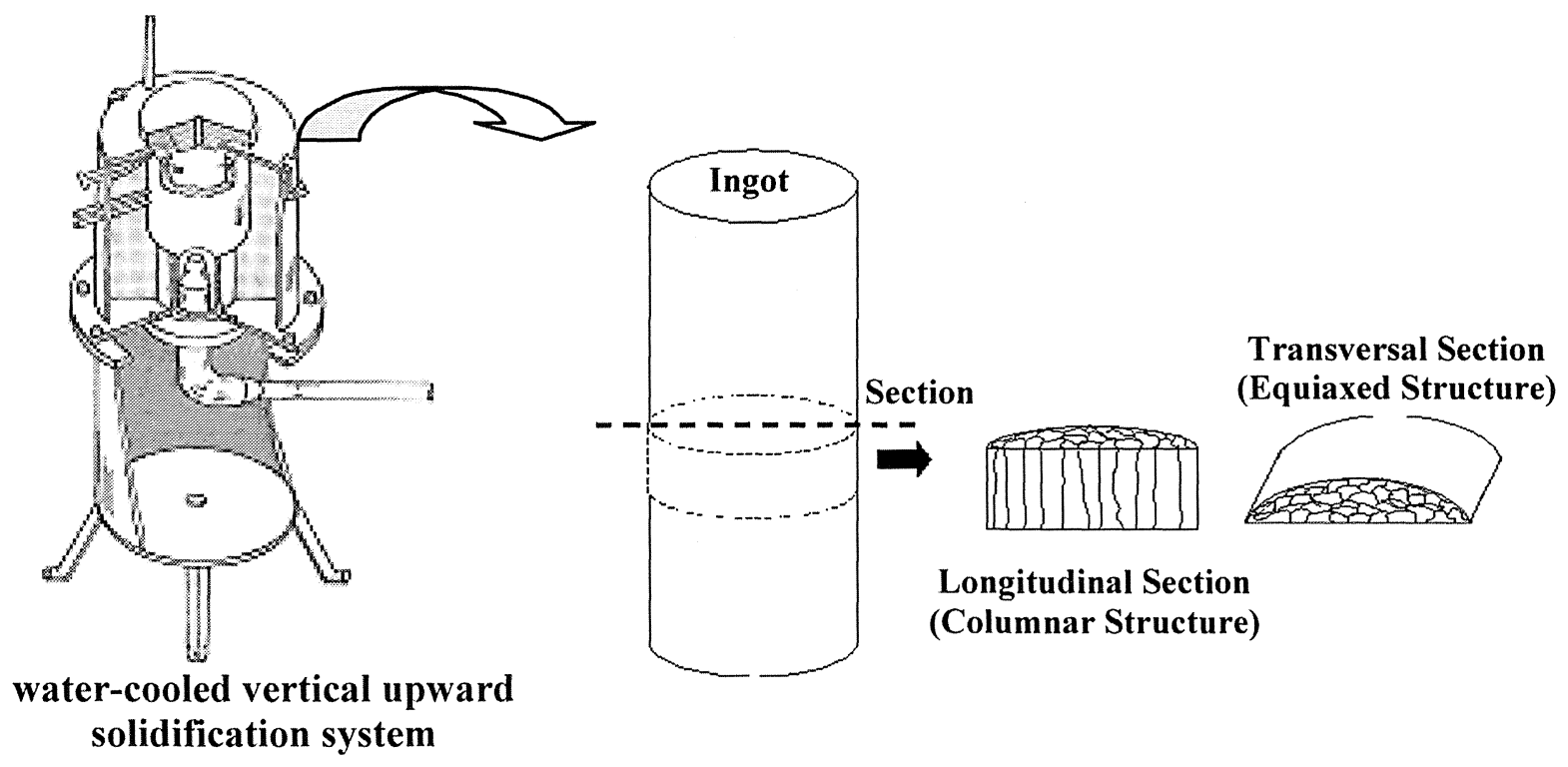

Figure 1. Schematic representation of the longitudinal (columnar) and transversal (equiaxed) sections.

Figura 1. Representación esquemática de obtención de las secciones longitudinales (columnares) y transversal (equiaxiales). 
Effects of the longitudinal and transversal structural grain morphologies upon the corrosion resistance of zinc and aluminium specimens W.R. Osório, C.A. Sigueira, C. M-A. Freire AND A. GARCía

Table I. Mean chemical composition of $\mathrm{Zn}$ and Al samples

Tabla I. Composición química media de las muestras del $\mathrm{Zn}$ y Al

\begin{tabular}{|c|c|c|c|c|c|c|c|}
\hline \multicolumn{2}{|c|}{ Element (wt\%) } & \multirow{2}{*}{$\begin{array}{r}\text { Zn } \\
99.97\end{array}$} & \multirow[t]{2}{*}{ Al } & \multirow{2}{*}{$\begin{array}{r}\mathrm{Fe} \\
0.015\end{array}$} & \multirow{2}{*}{$\frac{\mathrm{Pb}}{0.012}$} & \multirow{2}{*}{$\begin{array}{c}\mathrm{Si} \\
0.003\end{array}$} & \multirow{2}{*}{$\begin{array}{c}\text { other } \\
-\end{array}$} \\
\hline & ZInc & & & & & & \\
\hline & Aluminium & & 99.93 & 0.038 & $<0.001$ & 0.033 & - \\
\hline
\end{tabular}

\section{RESULTS AND DISCUSSION}

Figure 1 exhibits the schematic representation of the longitudinal and transversal sections presenting columnar and equiaxed structures, respectively. The cooled vertical upward solidification system allows a wide range of growth rates to be attained, permitting to obtain both coarse and fine columnar structures. It is well known that the way the heat flows across the metal and metal/mold interfaces, directly affects the evolution of solidification process and plays a notable role in determining the freezing conditions within the metal ${ }^{[7-11]}$.

In the present work the operational conditions used during solidification were intended to obtain columnar structures. In a previous work ${ }^{[18]}$, the comparison between coarse and fine structures in both columnar and equiaxed morphologies has permitted to concluded that coarser structures of both $\mathrm{Al}$ and $\mathrm{Zn}$ samples present better corrosion resistance than finer structures. The equiaxed morphology has proved to have a better corrosion resistance than the columnar morphology ${ }^{[18]}$.

The experimental results of the test EIS for both metals are presented in figure 2 ( $a$ and $b$ ) in Bode and Bode-Phase representation. Figure 2 (c and d) show the experimental polarization curves for $\mathrm{Al}$ and $\mathrm{Zn}$ samples, respectively. The corrosion current $\left(\mathrm{I}_{\mathrm{Corr}}\right)$ and corrosion potential $\left(\mathrm{E}_{\mathrm{Corr}}\right)$ values as well as impedance modulus and phase versus frequency are expressed in table II.

Analysis of the above experimental results and expressed values at table II, permits to conclude that there exists a similarity between corrosion behaviour of the longitudinal and transversal sections for aluminium samples. In the case of the EIS tests, both longitudinal and transversal sections have presented the impedance modulus and phase values of the same order. The polarization curves for $\mathrm{Al}$, have indicated a difference between these sections of $9 \%$ in terms of the corrosion rate $\left(\mathrm{I}_{\text {Corr }}\right)$ and about $4.5 \%$ in terms of the corrosion potential $\left(\mathrm{E}_{\mathrm{Corr}}\right)$. These scatters are very small when compared with those of a previous work ${ }^{[18]}$ where the columnar and equiaxed morphologies were analysed.

The zinc samples have also presented similar results in terms of the corrosion behaviour for both sections performed in EIS and polarization tests. In the $\mathrm{Zn}$ analyses, the observed scatters were about 1.22 times and $0.5 \%$, respectively for corrosion rate and corrosion potential. In general, by analysing the above results it is possible to conclude that the transversal section (from columnar structure castings) presents a similar corrosion resistance with regard to the longitudinal structure. The analysed equiaxed structure in this study can be seen as a pseudo-equiaxed structure. As reported previously, there exist a reasonable difference between the real equiaxed and columnar structures in terms of the corrosion behaviour ${ }^{[18]}$. This scatter can be explained due to differentiated growth and morphology formation. Heat flow conditions may generate finer or coarser grains, which can induce different corrosion resistances ${ }^{[18}$ and 19$]$. For commercially pure metals, the grains boundaries have a high influence upon the corrosion resistance due to the presence of defects, plastic deformation and small amount of segregated impurities. Thus, considering only the grain boundary effect, coarser grains will contribute to improve the corrosion resistance.

In figure 3 , it can be observed a microstructure of the aluminium sample with the chemical etching exhibiting the plastic deformation between neighbouring grain boundaries in two different magnifications.

\section{CONCLUSION}

In this study, the role of longitudinal (columnar) and transversal (equiaxed) sections of both commercially pure $\mathrm{Al}$ and $\mathrm{Zn}$ specimens and their corrosion resistance has been analysed. The experimental results permit to conclude that the 

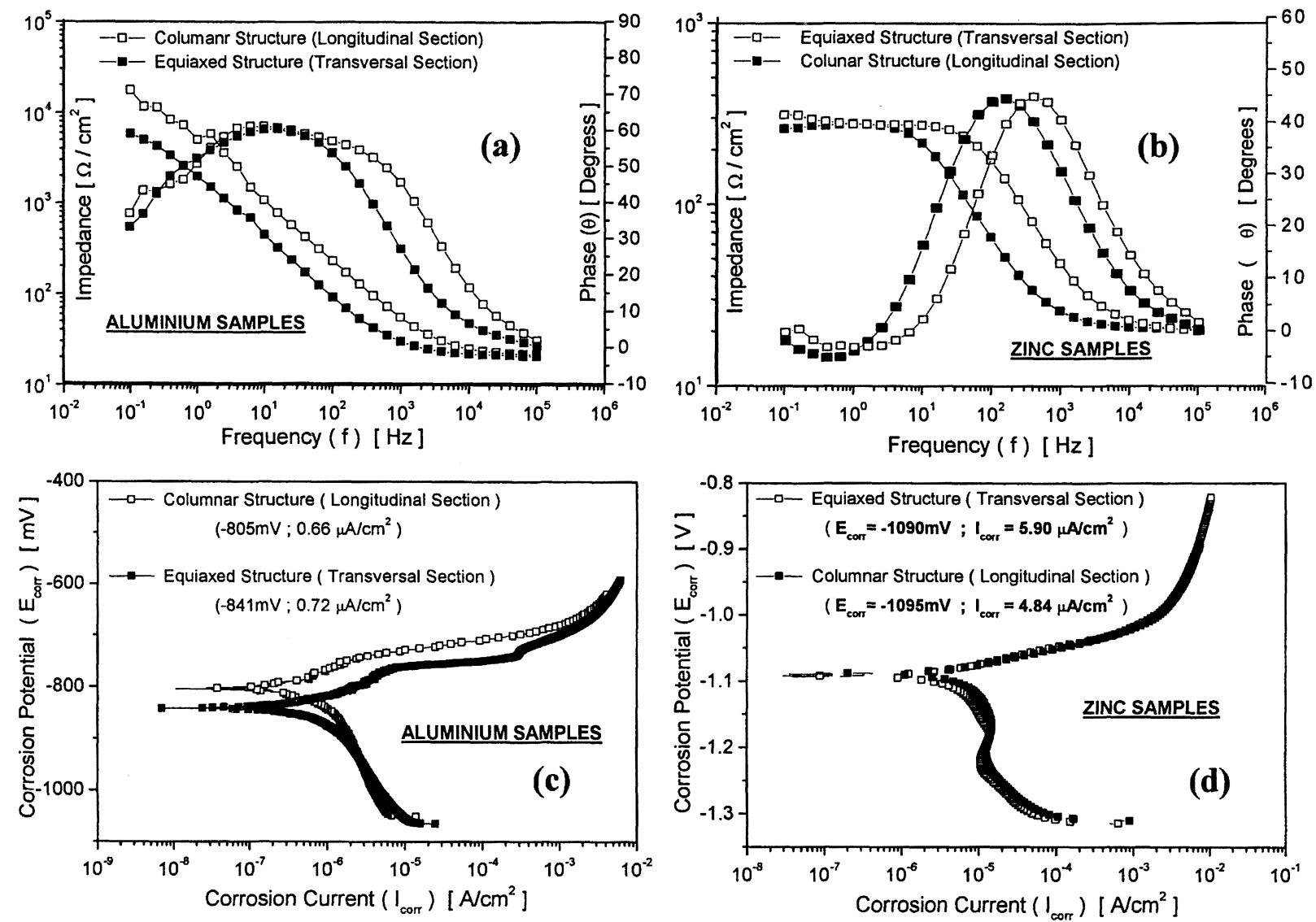

Figure 2. Comparison between longitudinal and transversal sections in Bode and Bode-Phase representation (a and b) and polarization curves (c and d) for Al and Zn samples, respectively.

Figura 2. Comparación de las secciones longitudinales y transversales en Bode y Bode-Phase representación (a y b) y curvas del polarización (c y d) de los especímenes de Al y Zn.

Table II. Experimental corrosion parameters obtained for longitudinal and transversal structures

Tabla II. Parámetros de la corrosión obtenidos experimentalmente para las estructuras longitudinales y transversales

\begin{tabular}{|c|c|c|c|c|}
\hline \multirow[t]{2}{*}{ Metal } & \multicolumn{2}{|r|}{ Parameters } & \multicolumn{2}{|c|}{ Structure } \\
\hline & & & Longitudinal & Transversal \\
\hline \multirow{8}{*}{ Aluminium } & \multirow{4}{*}{ Polarization } & $\mathrm{I}_{\text {Corr }}\left[\mu \mathrm{A} / \mathrm{cm}^{2}\right]$ & 0.66 & 0.72 \\
\hline & & $\Delta \mathrm{I}_{\text {Corr }}$ & \multicolumn{2}{|c|}{$9 \%$} \\
\hline & & $\mathrm{E}_{\text {Corr }}[\mathrm{mV}]$ & -805 & -841 \\
\hline & & $\Delta \mathrm{E}_{\mathrm{Corr}}$ & \multicolumn{2}{|c|}{$4.5 \%$} \\
\hline & \multirow{4}{*}{ E.I.S. } & $|\mathrm{Z}|\left[\mathrm{k} \Omega / \mathrm{cm}^{2}\right]$ & 18 & 6 \\
\hline & & $\Delta \mathrm{E}_{\text {Corr }}$ & \multicolumn{2}{|c|}{ (3 times) } \\
\hline & & $\theta / f[\% / H z]$ & $61.5^{\circ} ; 6$ & $61^{\circ} ; 16$ \\
\hline & & $\Delta E_{\text {Corr }}$ & \multicolumn{2}{|c|}{$0.8 \% ; 1.7$ times } \\
\hline \multirow{8}{*}{ Zinc } & \multirow{4}{*}{ Polarization } & $I_{\text {Corr }}\left[\mu \mathrm{A} / \mathrm{cm}^{2}\right]$ & 4.84 & 5.90 \\
\hline & & $\Delta \mathrm{I}_{\text {Corr }}$ & & \\
\hline & & $\mathrm{E}_{\text {Corr }}[\mathrm{mV}]$ & -1095 & -1090 \\
\hline & & $\Delta \mathrm{E}_{\text {Corr }}$ & & \\
\hline & \multirow{4}{*}{ E.I.S. } & $|\mathrm{Z}|\left[\mathrm{k} \Omega / \mathrm{cm}^{2}\right]$ & 0.27 & 0.3 \\
\hline & & $\Delta \mathrm{E}_{\text {Corr }}$ & \multicolumn{2}{|c|}{$11 \%$ (1.11 times) } \\
\hline & & $\theta / f\left[{ }^{\circ} / \mathrm{Hz}\right]$ & $44.8^{\circ} ; 403$ & $45^{\circ} ; 154$ \\
\hline & & $\Delta \mathrm{E}_{\text {Corr }}$ & \multicolumn{2}{|c|}{$0.4 \% ; 1.6$ times } \\
\hline
\end{tabular}


Effects of the longitudinal and transversal structural grain morphologies upon the corrosion resistance of zinc and aluminium specimens W.R. OSório, C.A. SiQueIra, C. M-A. Freire AND A. GARCía
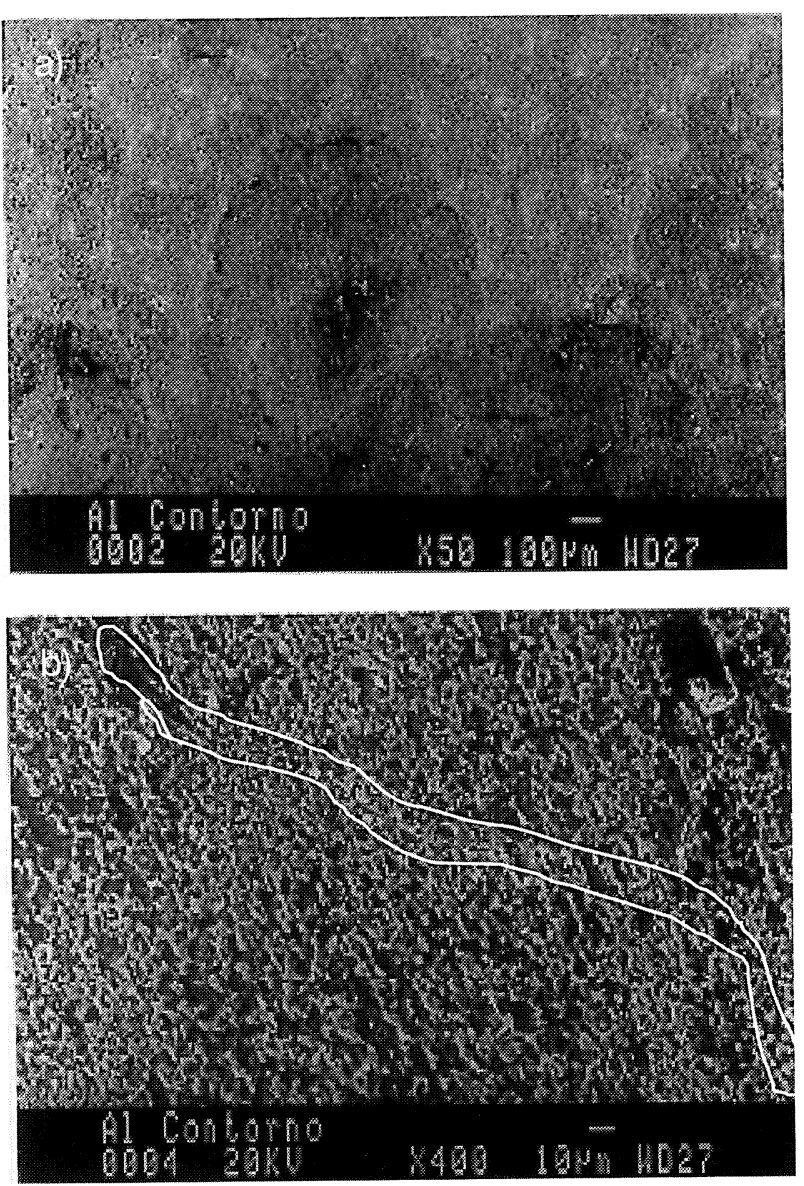

Figure 3. Micrograph of an Aluminium sample with the chemical etching evidencing expressive plastic deformation in grain boundaries.

Figura 3. Micrografía de la estructura del Aluminio con evidencia del ataque químico y la deformación en contornos de los granos.

transversal section (pseudo-equiaxed structure) presents a similar corrosion resistance than the longitudinal section (columnar structure).

\section{Acknowledgements}

The authors acknowledge financial support provided by FAEP-UNICAMP, FAPESP and CNPq.

\section{REFERENCES}

[1] A. Artigas, M. Paez, Y. Houbaert, A. Monsalve and D. Celentano, Rev. Metal. Madrid 38 (2002) 339-347.
[2] N.J. PeTCH, J. Iron Steel Inst. 174 (1953) 25-31.

[3] A. Lasalmonie and J. Strudel, J. Mater. Sci. 21 (1986) $1837-1852$.

[4] K.J. Kurzydlowski, B. Ralph, J.J. BucKi and A. Garbacz, Mat. Sci. Eng. A205 (1996) 127-132.

[5] W.R. Osório and A. Garcia, Mat. Sci. Eng. A325 (2002) 103-111.

[6] P. Donelan, Mater. Sci. Tech. 16 (2000) 261-269.

[7] W.R. Osório, C.A. Santos, J.M. Quaresma and A. García, Proc. Int. Conf. AMPT, vol. I, Madrid, Spain, 2001, J. M. Torralba (Ed.), 2001, pp. 207-215.

[8] J.M. Quaresma, C.A. Santos and A. García, Metall. Mater. Trans. 31A (2000) 3167-3178.

[9] C.A. Santos, J.M. Quaresma and A. García, J. Alloys Comp. 319 (2001) 174-186.

[10] H. PARK and J.A. SzPunar, Corros. Sci. 40 (1998) 525 545.

[11] P.R. Seré, J.D. Culcasi, C.I. Elsner and A.R. Di-SArli, Surf. Coat. Tech. 122 (1999) 143-149.

[12] K.G. Watkins, M.A. MCMAhon and W.M. Steen, Mat. Sci. Eng. A231 (1997) 55-61.

[13] T.T. Wong and G.Y. Liang, J. Mat. Proc. Tech. 63 (1997) 930-934.

[14] J.K. SHIN, J.H. SuH, J.S. KIM and S.J. KanG, Surf. Coat. Tech. 107 (1998) 94-100.

[15] A. Conde, R. Colaço, R. Vilar and J. DE Damborenea, Mater. Design 21 (2000) 441-445.

[16] G. Song, A. Atrens and M. Dareusch, Corros. Sci. 41 (1999) 249-273.

[17] J.C. Cuyas, G.W. Mugica, D.O. Tovio and A.C. GonZÁlez, Rev. Metal. Madrid 38 (2002) 139-149.

[18] W.R. Osório, C.M.A. Freire and A. García, Mater. Sci. Eng. A 402 (2005) 22-32.

[19] A. García, Solidificação: Fundamentos e Aplicações, Ed. UNICAMP, Campinas, Brasil, 2001.

[20] C.A. Sigueira, N. Cheung and A. García, Metall. Mater. Trans. 33A (2002) 2107-2118.

[21] V. Voort, Metallography: Principles and Practice, Ed. McGraw-Hill, New York, USA, 1989.

[22] C.L. Meade, Met. Finish. 98 (2000) 540-542.

[23] A. Conde and J. DE Damborenea, Corros. Sci. 39 (1997) 295-303.

[24] ASTM G3, Standard Recommended Practice for Conventions Applicable to Electrochemical Measurements in Corrosion Tests, Easton, USA, 1973, pp. 1093.

[25] M. Stern and A.L. Geary, J. Electrochem. Soc. 4 (1957) 56-63. 